\title{
Unregistered Artesian Well Management in Pasuruan, Indonesia: an Attempt to Protect Groundwater Resources
}

\author{
Heru Hendrayana ${ }^{1^{*}}$, Indra Agus Riyanto ${ }^{2}$, Azmin Nuha ${ }^{3}$ and Ahmad Rifan Khoirul Lisan ${ }^{4}$ \\ ${ }^{1}$ Geological Engineering Department, Faculty of Engineering, Universitas Gadjah Mada, Indonesia. ${ }^{2}$ Master Program on \\ Planning and Management of Coastal Area and Watershed, Faculty of Geography, Universitas Gadjah Mada, Indonesia. \\ ${ }^{3}$ Groundwater Working Group (GWWG), Faculty of Engineering, Universitas Gadjah Mada, Indonesia. ${ }^{4}$ Water, Society and \\ Policy MS Program, The University of Arizona, US.
}

Received: $2021-09-18$ Accepted: 2021-12-11

\section{Keywords:}

unregistered artesian wells; wasted groundwater; groundwater management

Correspondent email: heruhendrayana20@gmail.com

\begin{abstract}
The number of unregistered artesian wells increases every year in the northern slopes of Bromo Volcano, Pasuruan. Artesian wells are used for domestic needs and agricultural irrigation but are not followed by environmentally sound groundwater use. The purpose of this study is to assess the potential for groundwater, groundwater use, wasted groundwater, and recommendations for groundwater management. The groundwater potential was obtained by measuring the depth of the groundwater table, piezometric surface of artesian wells, and geoelectrical data. Water uses were obtained from calculations based on the Indonesian National Standard. The amount of wasted groundwater was obtained by comparing the groundwater potentials, groundwater uses, and groundwater discharges from unregistered artesian wells. Water transfer was assessed by selecting unregistered artesian wells with discharges able to fulfill the water demands of each village. Groundwater in the Sub-Districts of Gondang Wetan and Winongan has high potential consisting of 1 unconfined aquifer group and two confined aquifer groups. Gondang Wetan and Winongan Sub-Districts are characterized as wasting groundwater potential through unregistered artesian wells. The discharge flow of unregistered artesian wells exceeds the water needs ( $>100 \%)$ in Winongan and Gondang Wetan Sub-Districts. Groundwater can be managed by water transfer, closure of artesian wells, and regulation of artesian wells use. Water can be transferred to areas not covered by Artesian wells in 20 villages. The number of artesian wells used for water transfer is 20 with a discharge of 5-20 liters/s.
\end{abstract}

(2021 by the authors. Licensee Indonesian Journal of Geography, Indonesia.

his article is an open access article distributed under the terms and conditions of the Creative Commons

Attribution(CC BY NC) licensehttps///creativecommons.org/licenses/by-nc/4.0/.

\section{Introduction}

Deep Groundwater has been widely used as a main water source globally (Hebig et al., 2012; Msassuel et al., 2017; Habermehl, 2020; Hendrayana et al., 2021). One type of deep groundwater often used is water flowing from artesian wells. Artesian wells can be made by deep drilling until they penetrate confined aquifers. Water from artesian wells has several good characteristics; it is protected from contamination, especially that leaks from the ground surface (Cloutier et al., 2006; Yan et al., 2019). The water also has natural pressure to flow to the surface without being pumped (Shrestha et al., 2017; Velasco \& Capilla, 2019). However, currently, the number of artesian wells is increasing; this lowers the groundwater level and reduces the availability of groundwater (Medellín-Azuara et al., 2015; Luo \& Illman, 2016).

This problem also occurs in the northern slopes of Bromo Volcano in Pasuruan, especially in Gondang Wetan and Winongan Sub-Districts. The number of artesian wells in these Sub-Districts continues to increase every year. Without any permit and proper well construction, groundwater continuously goes to the wells to waste groundwater (Toulier et al., 2019). Many people use artesian wells because the area has limited surface water sources. Both Sub-Districts are classified as very dry based on the Standard Precipitation Index (SPI) (Khairani et al., 2018). Gondang Wetan and Winongan Sub-Districts are affected by the drought (Nahar, 2016). In addition, the two Sub-Districts do not have access to the Regional Drinking Water Company (PDAM) network. (Subekti, 2012). Although many have artesian wells in the two Sub-Districts, the water is not evenly distributed, so there are still dry areas.

It is necessary to study groundwater management in Gondang Wetan and Winongan Sub-Districts to achieve sustainable use of water resources. This study investigates the efficiency of groundwater use from artificial wells, so that groundwater is not wasted and can be distributed evenly in dry areas. This study was carried out by calculating community water use, groundwater potential, total artesian wells discharge, and groundwater use efficiency. The next target of this research is to recommend water transfer from 


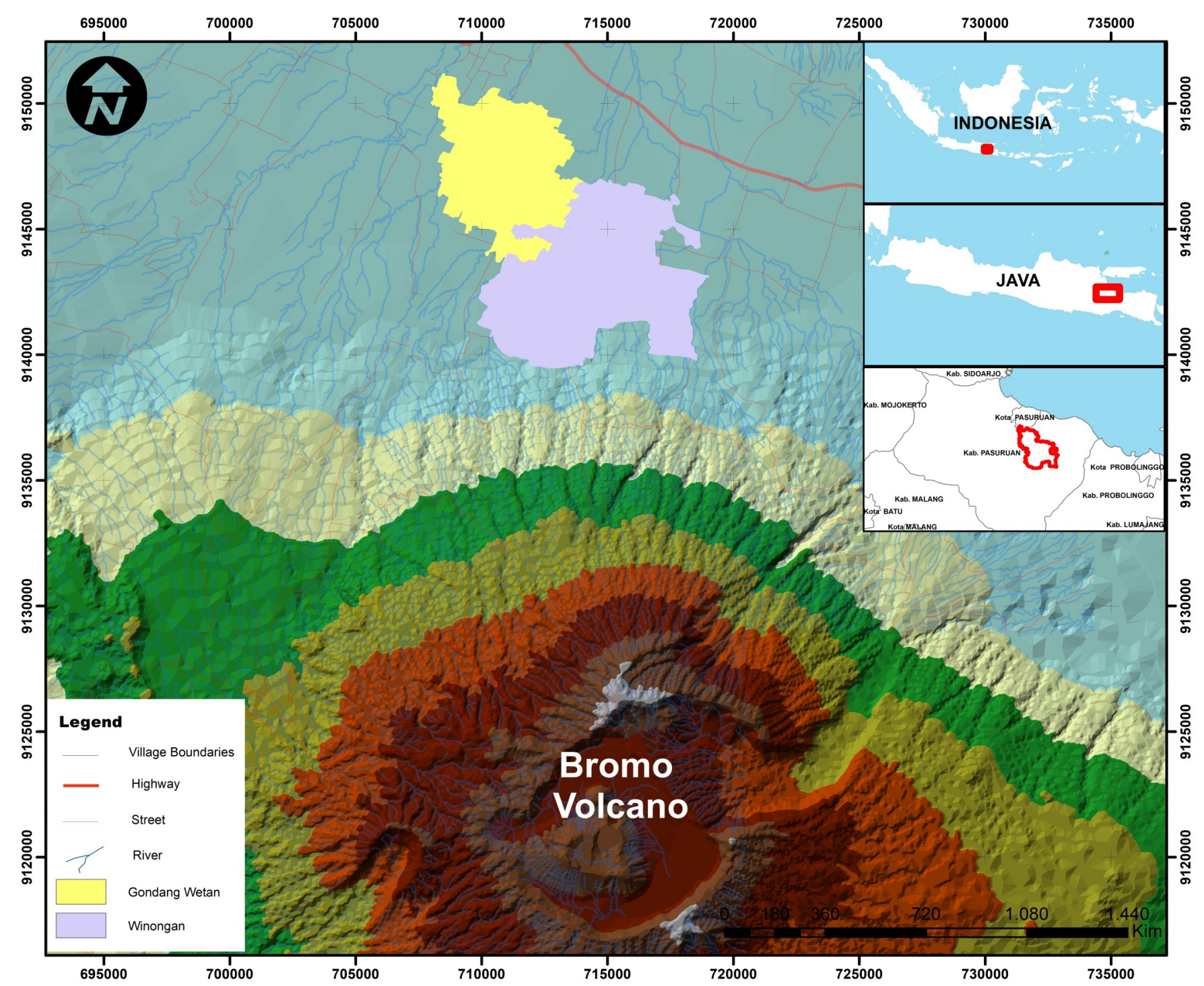

Figure 1. Study Area

(Basemap Source: Geospatial Information Agency(BIG), 2004)

artesian wells to dry areas in Winongan and Gondang Wetan Sub-Districts. Inefficient transfer of water from artesian wells is based on consideration of the discharge factor of each artesian well, the need for water, and the accessibility of the artesian wells from dry areas. This research is essential to conserve groundwater in Winongan and Gondang SubDistricts and can be used as a pilot project to study water transfer for arid regions.

Gondang Wetan and Winongan Sub-Districts are located at the foot of the Bromo-Tengger Volcano with UTM coordinates 710000-720000 $\mathrm{mU}$ and 9140000-9150000 (Figure 1). The study area has an area of $69.87 \mathrm{~km} 2$. Rainfall in the study area ranges from $1,800-2,500 \mathrm{~mm} /$ year with an average temperature of $23-25^{\circ} \mathrm{C}$ (Husniah et al., 2009). Gondang Wetan and Winongan Sub-Districts have two geological units: Rabano Tuff (Qvtr) and Middle Quarter Ringgit Volcanic Rocks (Qpv (t))(Santosa and Suwarti, 1992). Gondang Wetan and Winongan Sub-Districts are divided into three aquifer system units: productive aquifer with flow through inter-grain spaces, high productive aquifer, and medium productive aquifer with flow through gaps intergrain pores (Puspowardojo, 1984).

\section{Methods}

This study used primary data (from field measurements) and secondary data (Table 1). Field measurements resulted in a water table and piezometric surface. The number of measured shallow wells was 158 . The 353 artesian wells were measured and observed. Geoelectric surveys were carried out at 82 points. The secondary data used in this study were the Geological Map of Malang Sheet (Santosa and Suwarti, 1992), Hydrogeological Map of Kediri Sheet (Puspowardojo, 1984), Land Use Map from the Geospatial Information Agency (BIG), and water use data (BPS, 2021).

Water table and piezometric surface data were processed using interpolation in ArcGIS 10.8. The selected interpolation method has the lowest RMSE error value (Ohmer et al., 2017). Water table and piezometric surface data were essential to calculate groundwater potential at factor i (Equation 1) (Todd and Mays, 2005). The analysis of geoelectrical data was used to interpret the distribution of rock layers horizontally and vertically, especially relating the nature of rocks to the water. The results of the stratigraphic interpretation were significant to calculate $\mathrm{K}$ value (Telford et al., 1990). 


$\begin{array}{ll}\text { Q } & \text { : K xix A } \\ \text { Q } & \text { : groundwater discharge }\left(\mathrm{m}^{3} / \text { day }\right) \\ \text { K } & \text { : permeability coefficient }(\mathrm{m} / \text { day }) \\ \text { i } & \text { : hydraulic gradient } \\ \text { A } & \text { : area of aquifer }\left(\mathrm{m}^{2}\right)\end{array}$

To analyze water use, we employed the number of populations, area of irrigated rice fields, number of livestock, number of office employees, number of school students, number of health facilities, number of places of worship, number of restaurants, and number of industrial employees. Water use was calculated according to the Indonesian National Standard (Table 2). The water use results were then compared with the groundwater potential to determine whether the groundwater balance of the study area was surplus or deficit (Hendrayana \& Vicente, 2013; Hendrayana et al., 2020). In addition, a percentage of wasted groundwater was obtained from comparing the amount of water used with the total discharge of the artesian wells. Another percentage of wasted groundwater was also obtained by comparing the total discharge of the artesian wells with the amount of groundwater flow. The last stage was the buffering process of artesian wells with $400 \mathrm{~m}$ to obtain areas not covered by the artesian wells network. The unreachable areas need water transfer, so they are not dry. The water transfer process considered the location of the closest artesian wells and the water discharge that exceeded the water use. The analysis unit of this study is the village administration, both on the amount of groundwater flow, water use, wasted groundwater, and water transfer.

Table 1. Study Parameters

\begin{tabular}{|c|c|c|c|c|}
\hline Parameters & Tools & Scales & Sources & Analysis \\
\hline Water Table & GPS and Measuring Tape & $1: 100.000$ & Field Survey & Interpolation \\
\hline $\begin{array}{l}\text { Piezometric } \\
\text { Surface }\end{array}$ & GPS and Measuring Tape & $1: 100.000$ & $\begin{array}{l}\text { Field Survey } \\
\text { and secondary } \\
\text { data }\end{array}$ & Interpolation \\
\hline $\begin{array}{l}\text { Artesian Well } \\
\text { Discharges }\end{array}$ & $\begin{array}{l}\text { Pipe and Bucket (Volumetric } \\
\text { Method) }\end{array}$ & $1: 100.000$ & Field Survey & Table and map \\
\hline Statigraphy & $\begin{array}{l}\text { Geoelectric } \\
\text { VES (1D) and dipole-dipole } \\
(2 D)\end{array}$ & $1: 100.000$ & Field Survey & $\begin{array}{l}\text { 3D statigraphy } \\
\text { model }\end{array}$ \\
\hline Geology & Geology Map & $1: 100.000$ & $\begin{array}{l}\text { Field Survey and } \\
\text { Secondary Data }\end{array}$ & $\begin{array}{l}\text { Geoelectric } \\
\text { interpretation } \\
\text { validation }\end{array}$ \\
\hline Hydrogeology & Hydrogeology Map & $\begin{array}{l}1: 250.000 \\
\text { with } \\
\text { Modification }\end{array}$ & Secondary Data & $\begin{array}{l}\text { Geoelectric } \\
\text { interpretation } \\
\text { validation }\end{array}$ \\
\hline Borehole Data & Boreholes Report & $1: 100.000$ & Secondary Data & $\begin{array}{l}\text { Geoelectric } \\
\text { interpretation } \\
\text { validation }\end{array}$ \\
\hline Topography & Shape File & $1: 100.000$ & Secondary Data & Map \\
\hline Water use & Statistic Data & $1: 100.000$ & Secondary Data & SNI 2015 \\
\hline Landuse & Shape File & $1: 25.000$ & Secondary Data & $\begin{array}{l}\text { Water Transfer } \\
\text { Map }\end{array}$ \\
\hline
\end{tabular}

Table 2. Estimated Regression Function Heteroscedasticity Model

\begin{tabular}{|c|c|c|c|}
\hline Category & Standard & Category & Standard \\
\hline \multirow{3}{*}{ Domestic } & 60 liters/day/person (rural residents) & Worship & $3.000 /$ liters $/ \mathrm{m}^{2}$ \\
\hline & $\begin{array}{l}120 \text { liters/day/person (urban resi- } \\
\text { dents) }\end{array}$ & Hospital & 3000/liters/day/unit \\
\hline & 6 liters/day (sheep and pork) & Office & 10 liters/day/person \\
\hline \multirow[t]{2}{*}{ Livestock } & 40 liters/day (cow/buffalo) & Industry & 10 liters/day/person \\
\hline & 0.6 liters/day (Poultry) & Restaurant & 10 liters/day/chair \\
\hline Agriculture & 1 liters/second/ha & Education & 10 liters/day/person \\
\hline
\end{tabular}

Source : (BSN, 2015 with modification) 


\section{Results and Discussion}

The geoelectrical interpretation shows that the Gondang Wetan and Winongan Sub-Districts have four aquifer groups: aquifer 1, aquifer 2 , aquifer 3 , and aquifuge (Figure 3). Aquifer 1 is a free aquifer at 0-30 meters from the surface with alluvial deposits and tuff sandy clay materials. Aquifer 2 is a confined aquifer with tuff sandy clay materials at 50-80 meters. Aquifer 3 is a confined aquifer with gravelly sand materials at a depth of $>90$ meters. Aquifuge is between aquifers 1,2 , and 3 with the materials of tuff clay. The results of the geoelectrical interpretation are following drill log data and geological maps. The top layer is predominantly pyroclastic deposits, tuff, and the lower layer is mostly medium or coarse volcanic sand (Santosa and Suwarti, 1992; Toulier et al., 2019).

Aquifer 1 is shallow groundwater with a water table ranging from $80-10$ meters above sea level (masl) (Figure 4). Aquifer 1 has groundwater flowing from south to north. Aquifer 1 is measured from dug wells with depths of 10-30 meters. The water table mapping shows that the upstream has tight equipotential lines because they are close to the groundwater recharge area of the Bromo-Tengger Volcano. The equipotential lines are increasingly tenuous towards the north as the elevation declines and are an area for groundwater use. Aquifer 2 is a confined aquifer with a piezometric surface ranging from 60 to 22 masl. Aquifer 2 has groundwater flowing from south to north. Aquifer 2 was measured in dug wells 40-60 meters deep. The piezometric surface density of aquifer 2 is denser than that of water table aquifer 1 , due to the difference in hydrostatic pressure in the two different types of aquifers. Aquifer 3 is also a confined aquifer with a piezometric surface ranging from 56 to 16 masl. Aquifer 3 has the same relative direction of groundwater flow as aquifers 1 and 2, from south to north. Aquifer 3 is measured from artesian wells 70-80 meters deep. The piezometric surface pattern of aquifer 3 is similar to aquifer 2 because it is a confined aquifer. Groundwater level, piezometric surface, and groundwater flow patterns are in accordance with groundwater conditions on the existing hydrogeological map. And the aquifers belong to the aquifers in medium and high productivity (Puspowardojo, 1984).

Based on the calculation, groundwater potential in Winongan Sub-District is $32,363,137 \mathrm{~m} 3 /$ year (Figure 5) with confined aquifers 1 and 2 greater than unconfined aquifer 1 . The highest groundwater potential is in Kedungrejo Village with 3,487,351 m3/year, and the lowest is in Winongan Kidul Village with 659,497 m3/year. The discharge distribution for unconfined, confined 1, 2, and total discharge are predominantly distributed in the western part of Winongan Sub-District. The calculation of groundwater potential in Gondang Wetan Sub-District showed that it has a real potential of 20,831,097 m3/year groundwater (Figure 6), with potentials for confined aquifers 1 and 2 greater than unconfined aquifer 1 . The highest groundwater potential is in Brambang Village with 2,011,673 $\mathrm{m} 3$ /year, and the lowest is in Sekarputih Village with $465,688 \mathrm{~m} 3 /$ year. The discharge distribution for unconfined, confined 1,2 , and total discharge is predominantly distributed in the western part of Gondang Wetan Sub-District.

The calculation of the total groundwater use in Winongan Sub-District shows that the annual total groundwater use is 2,267,400 $\mathrm{m} 3$ (table 3). The highest use is in Gading Village of $228,168 \mathrm{~m} 3 /$ year, and the lowest is in Sidepan Village of $64,934 \mathrm{~m} 3$ /year. In all villages in Winongan Sub-District, the percentage of water use is below $30 \%$ and is classified as low and safe (Hendrayana \& Vicente, 2013; Hendrayana et al., 2020). All villages in Winongan Sub-District have a surplus groundwater balance.

The total use of groundwater in Gondang Wetan SubDistrict is 2,490,353 m3/year (table 4), with the highest in Karangsentul Village $(329,661 \mathrm{~m} 3 /$ year) and the lowest in Kersikan Village (78,823 m3/year). In all villages in Gondang Wetan Sub-District, the percentage of water use is below $30 \%$. The rate of water use is classified as low and safe (Hendrayana \& Vicente, 2013; Hendrayana et al., 2020). All villages in Gondang Wetan Sub-District have a surplus groundwater balance.

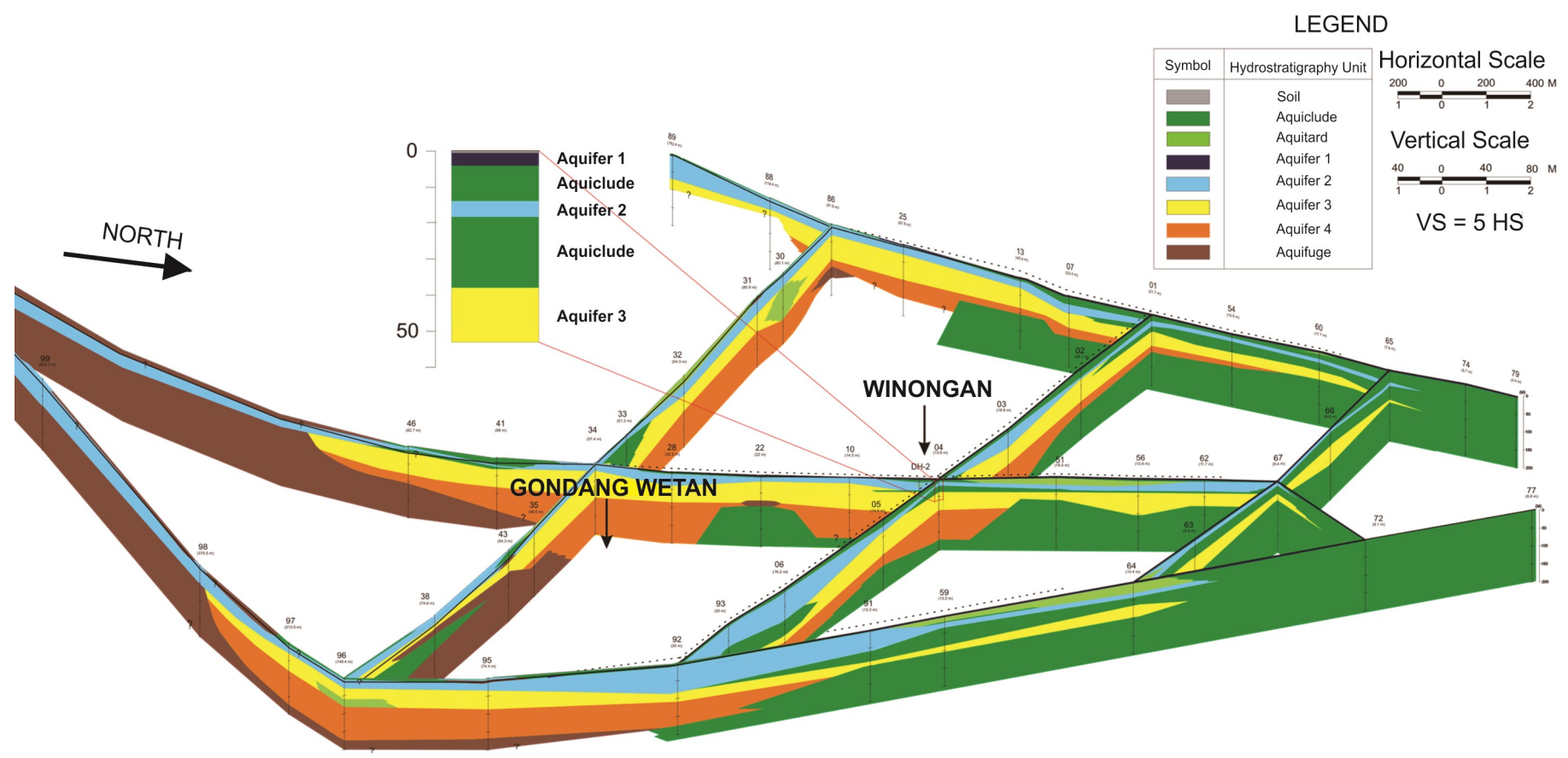

Figure 3. Hydro-stratigraphy Unit in Study Area (Hendrayana, et al., 2008) 


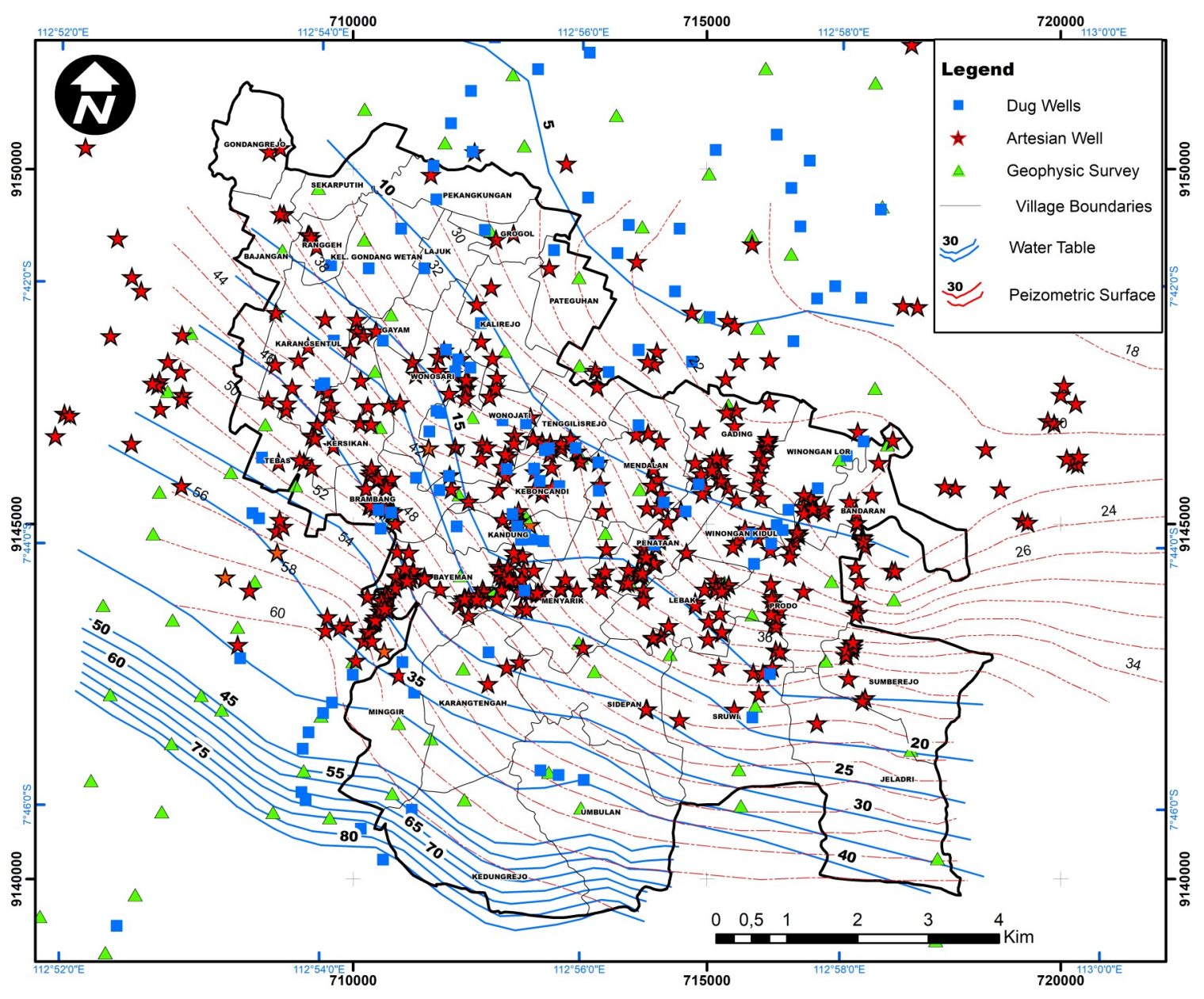

Figure 4. Water Table and Piezometric Surface in Study Area

(Basemap Source: Geospatial Information Agency (BIG), 2004)

\section{Groundwater Potential in Winongan Subdistrict}

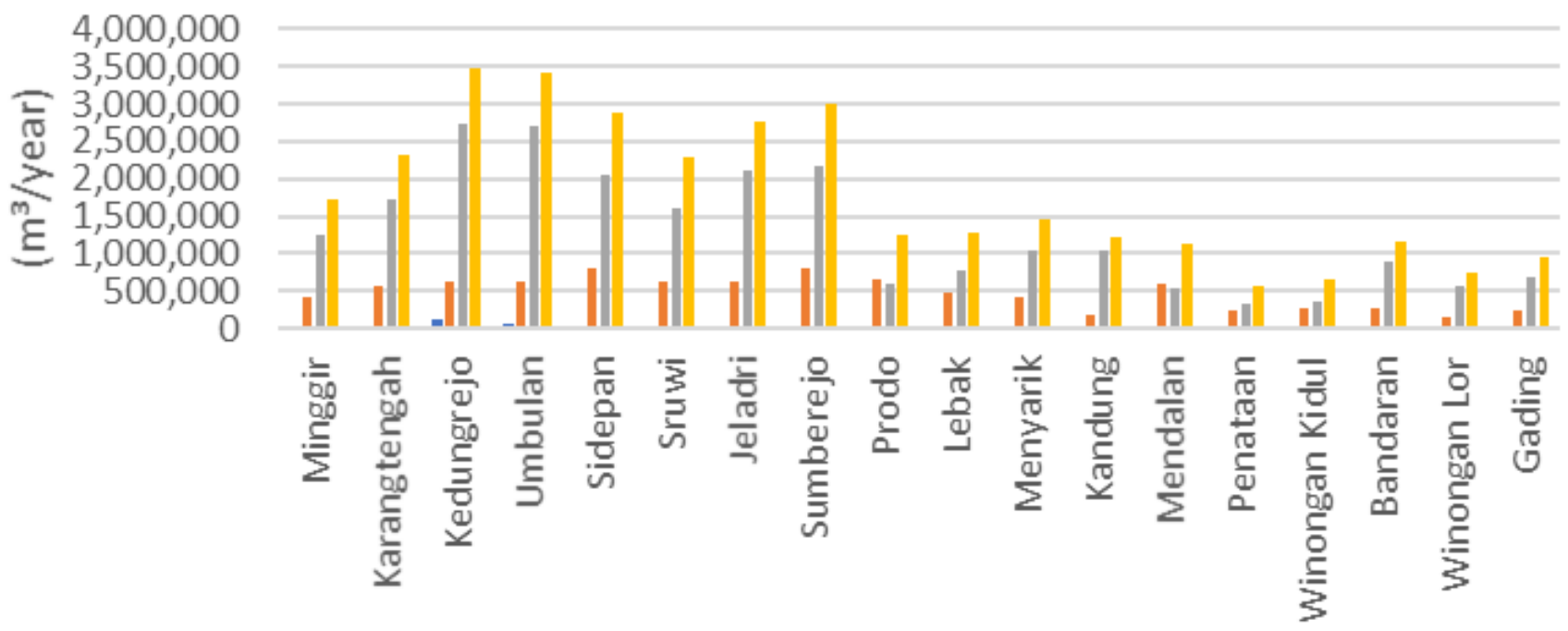

Villages

Unconfined aquifer $\quad$ Confined aquifer 1 Confined aquifer 2 Total Discharge

Figure 5. Calculation of Groundwater Potential in Winongan Sub-District 


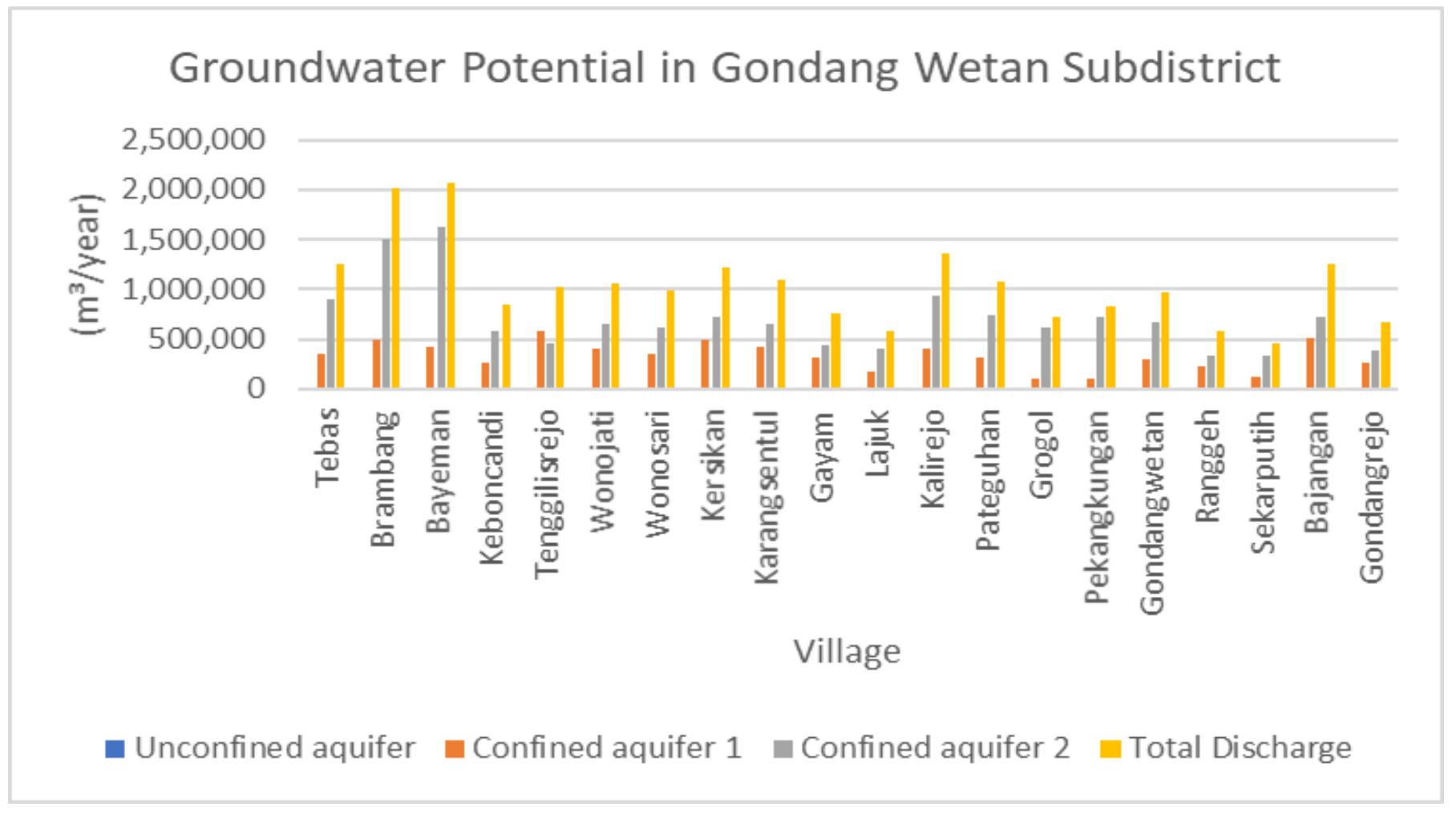

Figure 6. Calculation of Groundwater Potential in Gondang Wetan Sub-District

Table 3. Groundwater Use Rate in Winongan Sub-District

\begin{tabular}{lrccc}
\hline \multicolumn{1}{c}{ Village } & $\begin{array}{c}\text { Groundwater } \\
\text { Discharge } \\
(\mathrm{m} 3 / \mathrm{yr})\end{array}$ & $\begin{array}{c}\text { Total Groundwater } \\
\text { Use }(\mathrm{m} 3 / \mathrm{yr})\end{array}$ & $\begin{array}{c}\text { Balance } \\
(\mathrm{m} 3 / \mathrm{yr})\end{array}$ & $\%$ \\
\hline Minggir & $1,720,235$ & 124,123 & $1,596,112$ & 7.22 \\
Karangtengah & $2,327,318$ & 106,117 & $2,221,200$ & 4.56 \\
Kedungrejo & $3,487,351$ & 151,682 & $3,335,669$ & 4.35 \\
Umbulan & $3,407,205$ & 115,707 & $3,291,498$ & 3.40 \\
Sidepan & $2,895,499$ & 64,934 & $2,830,565$ & 2.24 \\
Sruwi & $2,278,048$ & 100,354 & $2,177,694$ & 3.41 \\
Jeladri & $2,768,839$ & 108,346 & $2,660,493$ & 5.87 \\
Sumberejo & $2,995,601$ & 175,858 & $2,819,742$ & 9.67 \\
Prodo & $1,264,142$ & 122,182 & $1,141,959$ & 8.18 \\
Lebak & $1,275,134$ & 104,358 & $1,170,776$ & 9.46 \\
Menyarik & $1,472,277$ & 139,316 & $1,332,961$ & 5.80 \\
Kandung & $1,235,829$ & 71,734 & $1,164,095$ & 15.04 \\
Mendalan & $1,121,028$ & 168,635 & 952,393 & 23.90 \\
Penataan & 582,231 & 139,181 & 443,049 & 15.40 \\
Winongan Kidul & 659,497 & 101,533 & 557,964 & 10.92 \\
Bandaran & $1,171,102$ & 127,895 & $1,043,207$ & 15.80 \\
Winongan Lor & 742,163 & 117,276 & 624,887 & 23.78 \\
Gading & 959,639 & 228,168 & 731,471 & - \\
\multicolumn{1}{c}{ Total } & $32,363,137$ & $2,267,400$ & $30,095,737$ & \\
\hline
\end{tabular}

Source: processing results (2021) 
Table 4. Groundwater Use Rate in Gondang Wetan Sub-District

\begin{tabular}{lrccc}
\hline \multicolumn{1}{c}{ Village } & $\begin{array}{c}\text { Groundwater } \\
\text { Discharge } \\
(\mathrm{m} 3 / \mathrm{yr})\end{array}$ & $\begin{array}{c}\text { Total Groundwater } \\
\text { Usage }(\mathrm{m} 3 / \mathrm{yr})\end{array}$ & $\begin{array}{c}\text { Groundwater Balance } \\
\left(\mathrm{m}^{3} / \mathrm{yr}\right)\end{array}$ & $\%$ \\
\hline Tebas & $1,248,413$ & 112,033 & $1,136,380$ & 8.97 \\
Brambang & $2,011,673$ & 88,287 & $1,923,386$ & 4.39 \\
Bayeman & $2,070,081$ & 168,878 & $1,901,203$ & 8.16 \\
Keboncandi & 843,484 & 126,174 & 717,310 & 14.96 \\
Tenggilisrejo & $1,029,273$ & 117,990 & 911,283 & 11.46 \\
Wonojati & $1,065,759$ & 133,473 & 932,287 & 12.52 \\
Wonosari & 985,238 & 138,403 & 846,834 & 6.45 \\
Kersikan & $1,222,510$ & 78,823 & $1,143,687$ & 30.35 \\
Karangsentul & $1,086,260$ & 329,661 & 756,599 & 12.57 \\
Gayam & 765,024 & 96,184 & 668,839 & 13.89 \\
Lajuk & 586,195 & 81,434 & 504,761 & 9.86 \\
Kalirejo & $1,358,152$ & 133,907 & $1,224,245$ & 10.73 \\
Pateguhan & $1,072,092$ & 115,016 & 957,076 & 11.01 \\
Grogol & 725,568 & 79,901 & 645,667 & 12.02 \\
Pekangkungan & 829,151 & 99,661 & 729,489 & 14.03 \\
Gondangwetan & 969,508 & 136,004 & 17.46 \\
Ranggeh & 575,761 & 100,555 & 833,504 & 22.85 \\
Sekarputih & 465,688 & 106,406 & 475,206 & 8.17 \\
Bajangan & $1,255,878$ & 102,598 & 359,282 & 21.79 \\
Gondangrejo & 665,389 & 144,964 & $1,153,280$ & - \\
\multicolumn{1}{c}{ Total } & $20,831,097$ & $2,490,353$ & 520,425 & \\
\hline
\end{tabular}

Source: processing results (2021)

Comparison of groundwater discharged from Artesian Wells (QAW) to Total Groundwater Flow (QG) in Winongan Sub-District shows that 7 villages have a value of more than 100\% (Figure 7). The distribution pattern with more than $100 \%$ is in the north and the middle. The result indicates that a lot of groundwater in Winongan Sub-District is wasted. The wasted groundwater reduces the potential for groundwater in the surrounding villages and lowers piezometric surfaces. This result is also proportional to the rate of comparison of artesian wells discharge (QAW) to water use (QWU) in Winongan Sub-District, where the entire village is $>100 \%$. The distribution pattern with the percentage of $>100 \%$ is in the middle and the south. This means that the water of the artesian well that comes out is more than the community needs.

Comparison of wasted groundwater from Artesian Wells (QAW) to Total Groundwater Flow (QG) in Gondang Wetan Sub-District shows that 8 villages have a value of more than $100 \%$ (Figure 7). The distribution pattern with more than $100 \%$ is in the middle and the north. This result indicates that a lot of groundwater in Gondang Wetan SubDistrict is wasted. The wasted groundwater reduces groundwater potential in the surrounding villages and decreases piezometric surfaces. This result is also proportional to comparing artesian wells discharge (QAW) to water use (QWU) in Gondang Wetan Sub-District. Each of its 13 villages has a percentage of more than $100 \%$.
Information: Total Groundwater Flow (QG), Artesian Well Discharge (QAW), Water Use (QWU), Percentage of Groundwater Wasted from Comparison of Artesian Wells with Groundwater Potential (QAW/QG), and Percentage of Groundwater Wasted from Comparison of Water Use with Artesian Wells (QAW/QWU).

The distribution pattern with more than $100 \%$ is in the middle and the south. This means that the water of the artesian well that comes out is more than the community needs. The results of the comparison of wasted groundwater from Artesian Wells (QAW) to groundwater potential (QG) and the comparison of artesian wells discharge (QAW) to water use (QWU) show that a lot of artesian wells water is wasted.

Groundwater from artesian wells in Winongan and Gondang Wetan Sub-Districts is wasted very significantly. This causes environmental impacts, one of which is the decreasing discharge in Umbulan Spring year to year and more artesian wells (Toulier et al., 2019). The same pattern happens in many parts of the world, such as in Queensland, Australia. An increase in the number of artesian wells from 1900-2015, followed by an increase in water use (Kent et al., 2019), has caused groundwater decline in this city. The same pattern also occurs in North Africa; the intensive use of artesian wells and artesian springs from 1940-2010 has declined groundwater levels in this area (Massuel et al., 2017). Ontario, Canada is also experiencing the same thing. 


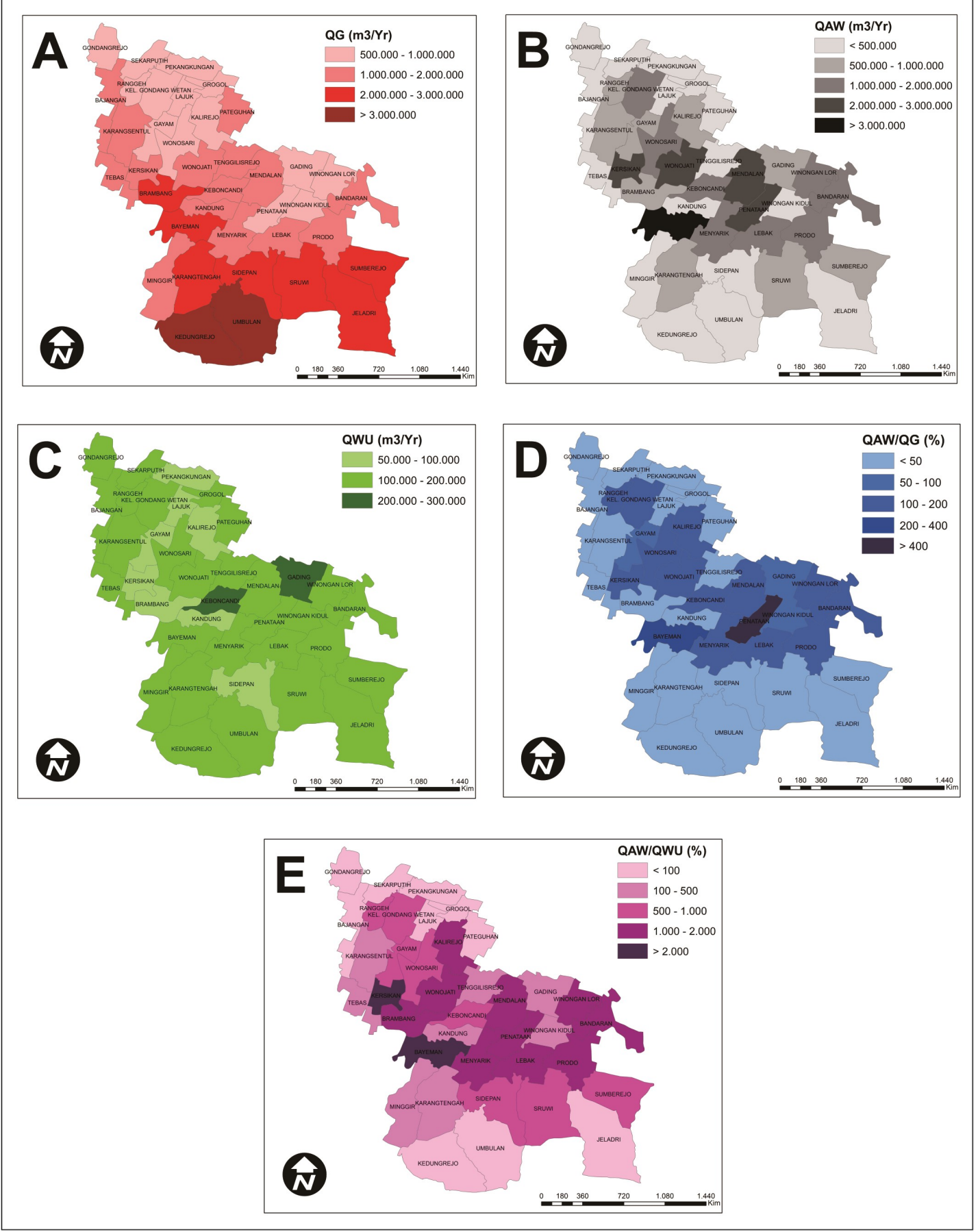

Figure 7. Comparison of QG, QAW, QWU, QAW/QG and QAW/QWU in Gondang Wetan Sub-District (Basemap Source: Geospatial Information Agency(BIG), 2004)

There is an increasing number of artesian wells in this city, followed by increasing groundwater extraction activities. This has declined the groundwater level in Ontario (Luo and Illman, 2016). On a bigger scale, such as in Australia's Great Artesian Basin, an increasing number of artesian wells and continuous groundwater extractions have depleted groundwater storage (Habermehl, 2019). This problem has caused several artesian wells and artesian springs to stop flowing.

Fortunately, in the research area, there are no artesian wells and artesian springs that have stopped flowing. Preventive measures can still be taken to prevent what has happened in Australia's Great Artesian Basin from occurring in the study area. In addition, all unregistered artesian wells are not adequately cased in the study area. If this is not taken seriously, the condition in Jordan can quickly happen in the study area. In Jordan, many artesian wells are not correctly completed with the proper casing. This problem has resulted in the groundwater mixing with salt from the salt lenses (Salameh and Tarawneh, 2017).

The artesian wells water is predominantly used for agriculture in paddy fields (Khasanah et al., 2021) (Figure 8). The artesian wells in rice fields are allowed to flow continuously to waste a lot of their water. A water transfer system can be created to allocate the water to villages not covered by the artesian wells network to reduce wasted artesian wells water. The water from the selected artesian wells can be transferred with discharges ranging from 5-20 liters/second (Table 5). The artesian wells can meet community water needs in areas not covered by the water network buffer (Figure 4). The number of villages not covered by the water network buffer is 20 , and the required artesian well is 20 . 


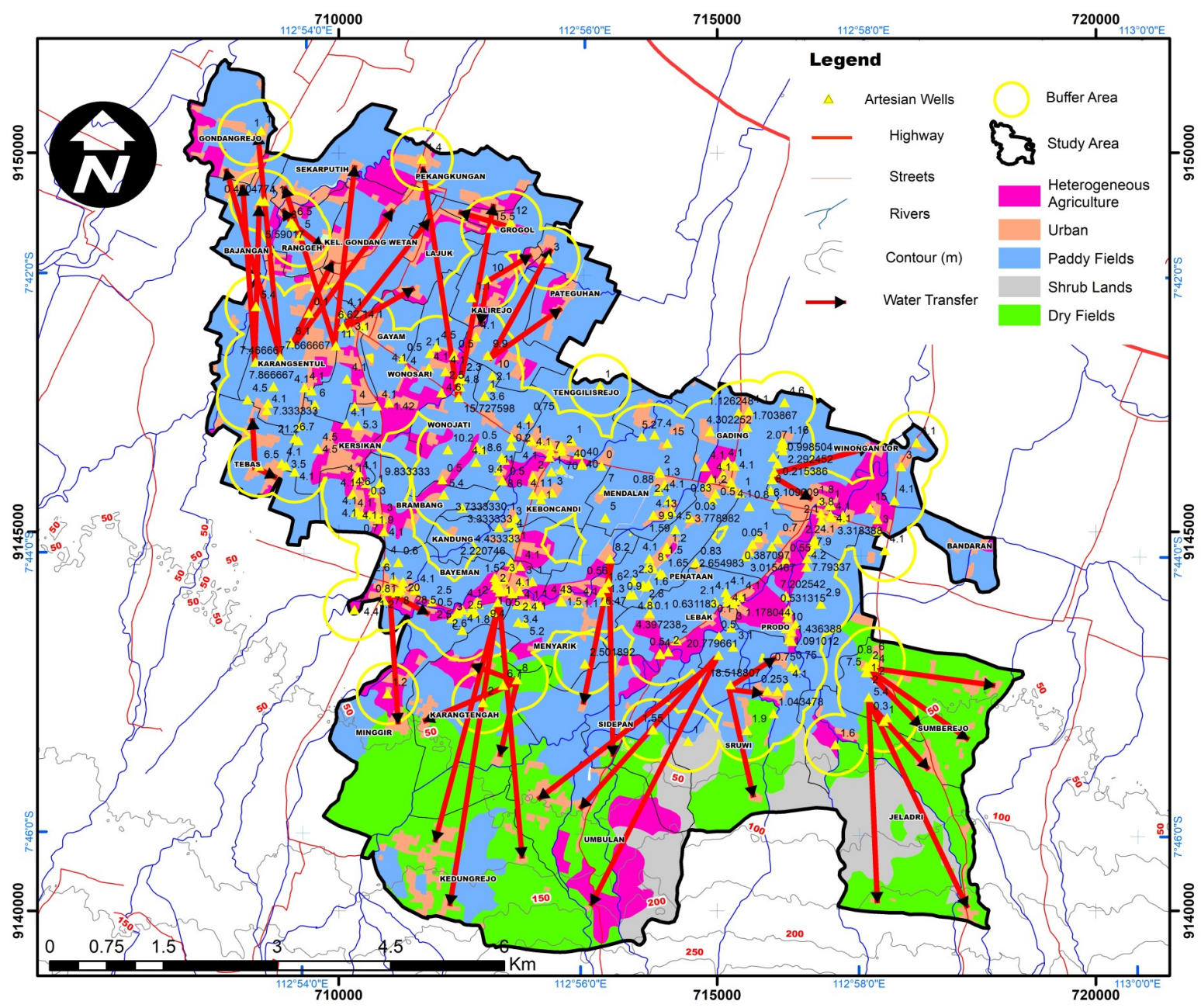

Figure 8. Water Transfer in Study Area

(Basemap Source: Geospatial Information Agency(BIG), 2004)

The artesian wells that can supply villages currently not covered by the water network buffer are evenly distributed in Winongan and Gondangwetan Sub-Districts. The distribution of the artesian wells is in the southern and northern areas. In the north part, in Gondang Wetan SubDistrict, water can be distributed through pipes carried out by gravity, but water cannot be transferred by gravity in the north part of Winongan Sub-District. In the northern part of Winongan Sub-District, pumping is necessary because there are no springs or boreholes in the upper zone. The north zone of Winongan Sub-District is included in the lowmedium groundwater productivity zone. Another option is dropping a tanker truck if developing a water pipe system is not evident in the northern part.

The smallest groundwater discharge amount of the artesian well is $157,680 \mathrm{~m} 3 /$ year, and the highest is 655,949 $\mathrm{m} 3 /$ year. While the lowest water use is $49,950 \mathrm{~m} 3 /$ year, and the highest is $135,276 \mathrm{~m} 3 /$ year. Umbulan, Kedungrejo, and Sidepan village water needs can also be met from the Umbulan Spring; However, a different artesian well is preferred because Umbulan Spring is already overburdened to meet the bulk water source of the City of Surabaya. Likewise, Banyu Biru Spring can fulfill water demands in Sumberejo and Jeladri villages; however, it is not used because it has been used for other purposes.

In addition, it is necessary to close artesian wells in agricultural areas that are rarely used. Besides, A system to open and close the artesian wells is often used, and the prohibition against constructing new artesian wells is also necessary. Artesian wells closure program is also implemented in Yemen to reduce the impact of excessive groundwater exploitation (T. Taher et al., 2012). Prohibitions and restrictions of constructions of new artesian wells have also been carried out in Iran using government regulations (Stevanovic \& Iurkiewicz, 2009). This measure is possibly implemented in this research area where unregistered artesian wells increase yearly.

Another way to reduce groundwater wasting can be seen in the United States. Research for alternative water sources for irrigation demands has been carried out extensively in this country. Many farmers have switched from groundwater to surface water from extensive damming (Schlager, 2006). In the study area, irrigation from surface water is only found in Pateguhan Village, the lower part of Winongan SubDistrict. In contrast, the upper parts of the Winongan and Gondang Wetan Sub-Districts are not supplied by surface water irrigation, so the farmers use artesian wells. By seeing what is implemented in the US, we can build or extend a surface water-sourced irrigation system to supply farming water needs in the study area. This measure is possibly reducing groundwater waste. Another effort can reduce the groundwater waste and add more artesian wells to mobilize local communities for more effective supervision (Taher, 2016). However, this measure is quite improbable to be 
Table 5. Water Transfer Management in Study Area

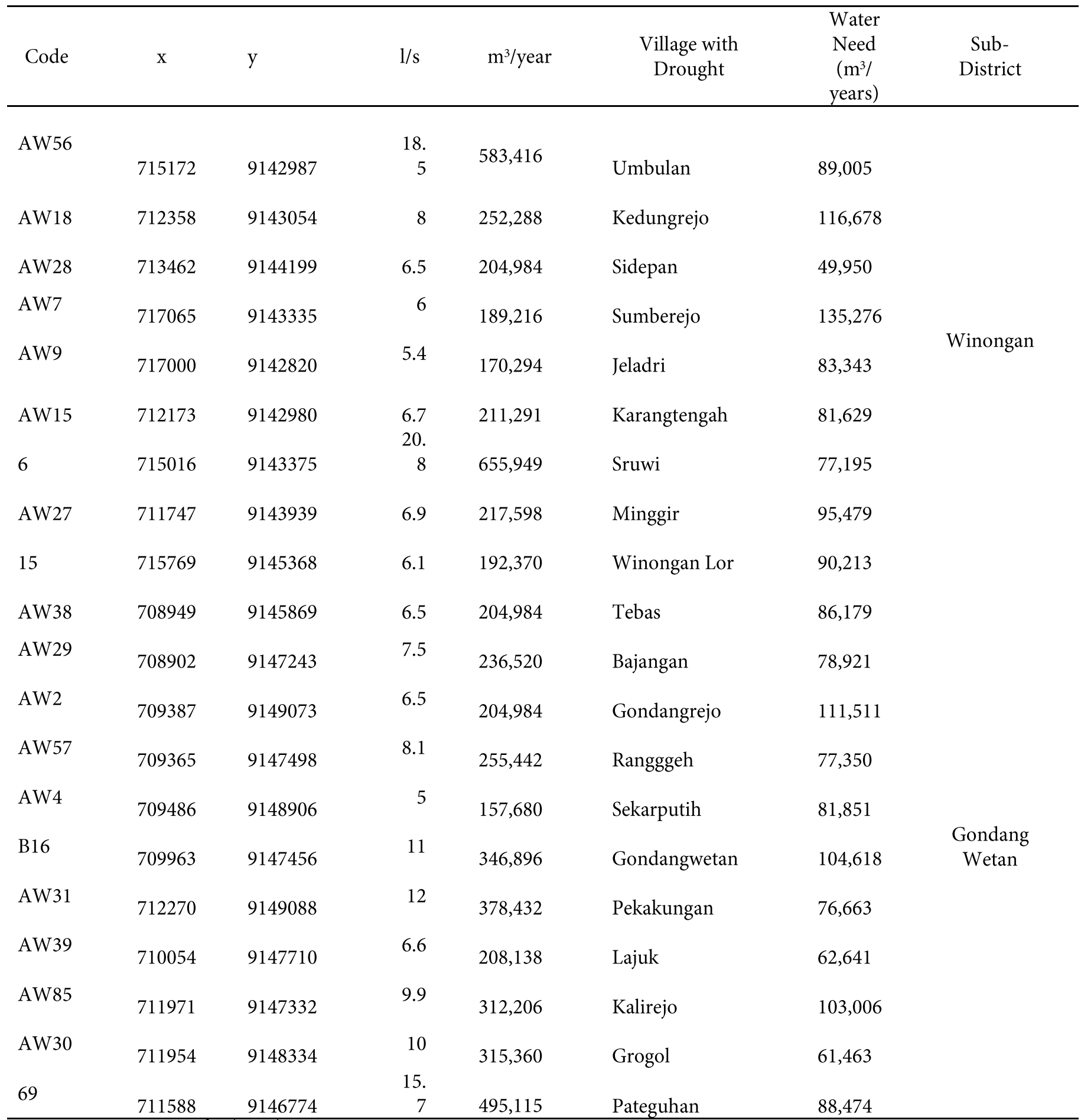

Source: processing results (2021)

implemented in the study area as the whole community members use and dig more unregistered artesian wells for irrigation and domestic uses (Khasanah et al., 2021).

\section{Conclusion}

The aquifer in the study area has high groundwater potential and has three aquifer layers - 1 unconfined and two confined layers. Many unregistered artesian wells water in Winongan and Gondang Wetan Sub-Districts is wasted. All artesian wells in all villages in Winongan and Gondang Wetan Sub-Districts discharge water that exceeds village water needs $(>100 \%)$. The distribution pattern with more than $100 \%$ is found in the central and southern parts of the
Winongan and Gondang Wetan Sub-Districts. In addition, the distribution with the percentage of more than $100 \%$ of discharged groundwater from Artesian Wells to Total Groundwater Flow is in the central and northern parts of Winongan and Gondang Wetan Sub-Districts. Excessive artesian wells can be managed using water transfer for areas not covered by the artesian groundwater network, mainly in the central, southern, and northern parts of Winongan and Gondang Wetan Sub-Districts using groundwater more than $100 \%$. A water transfer system through pipes using the gravity method can be applied in Gondang Wetan SubDistrict. Still, for Winongan District, water transfer must be carried out using a pumping system or water dropping with tanker trucks. In addition, it is necessary to close artesian 
wells which are not frequently used in agricultural areas, implement an open and closing system of artesian wells, and prohibit the construction of new artesian wells.

\section{Acknowledgment}

The author would like to thank all who have supported all processes of this paper, especially the World Agroforestry (ICRAF), Danone Aqua, University of Montpellier, and Department of Geological Engineering Faculty of Engineering Universitas Gadjah Mada ”

\section{References}

BPS. (2021). Pasuruan Regency in Figures 2021. Badan Pusat Statistik.

BSN. (2015). Penyusunan Neraca Spasial Sumber Daya Alam Bagian 1: Sumber Daya Air - The Development of Spatial Balance of Natural Resources - Part 1: Water Resources. SNI 6728.1:2015. Badan Standardisasi Nasional.

Cloutier, V., Lefebvre, R., Savard, M. M., Bourque, É., \& Therrien, R. (2006). Hydrogeochemistry and groundwater origin of the Basses-Laurentides sedimentary rock aquifer system, St. Lawrence Lowlands, Québec, Canada. Hydrogeology Journal, 14 (4), 573-590. https://doi.org/10.1007/s10040-005-0002-3

Habermehl, M. A. (2020). Review: The evolving understanding of the Great Artesian Basin (Australia), from discovery to current hydrogeological interpretations. Hydrogeology Journal, 28(1), 13-36. https://doi.org/10.1007/s10040-019-02036-6

Hebig, K. H., Ito, N., Scheytt, T., \& Marui, A. (2012). Review: Deep groundwater research with focus on Germany. Hydrogeology Journal, 20(2), 227-243. https://doi.org/10.1007/s10040-0110815-1

Hendrayana, H., Widyastuti, M., Riyanto, I. A., Nuha, A., and Aprimanto, B (2020). Neraca Airtanah Cekungan Airtanah (CAT) Menoreh dan Wates Kabupaten Kulon Progo Groundwater Balance of Menoreh and Wates Groundwater Basins, Kulon Progo Regency. Geomedia, 18(2), 10-29. https:// doi.org/10.21831/gm.v18i2.33636

Hendrayana, H., Nuha, A., Riyanto, I. A., Aprimanto, B., Geologi, D. T., Teknik, F., \& Gadjah, U. (2021). Kajian Perubahan Muka Airtanah di Cekungan Airtanah Yogyakarta-Sleman - Study of Groundwater Changes in Yogyakarta-Sleman Groundwater Basin. Majalah Geografi Indonesia, 35(1), 30-44. https:// doi.org/10.22146/mgi.62396

Hendrayana, H., Riyanto, I. A., \& Nuha, A. (2020). Tingkat Pemanfaatan Airtanah di Cekungan Airtanah (CAT) Yogyakarta-Sleman - Groundwater Use Rate in YogyakartaSleman Groundwater Basin. Geodika: Jurnal Kajian Ilmu Dan Pendidikan Geografi, 4(2), 127-137. https://doi.org/10.29408/ geodika.v4i2.2643

Hendrayana, H., \& Vicente, V. A. D. S. (2013). Cadangan Air Tanah Berdasarkan Geometri Hdan Konfigurasi Sistem Akuifer Cekungan Air Tanah Yogyakarta-Sleman - Groundwater Reserves Based on Geometry and Aquifer System Configuration of Yogyakarta-Sleman Groundwater Basin. Seminar Nasional Kebumian Ke-6, 356-370.

Hendrayana, H., Putra, D.P.E, and Cahyahadi, W. 2008. Final Report The Study to Delineated Recharge Area of Spring and to Quantify the Recharge Area of Pasuruan Site. Report. Pasuruan: PT Tirta Investama.

Husniah, R., Sholichin, M., \& Chandrasasi, D. (2009). Analisa pengaruh perubahan tata guna lahan terhadap erosi, sedimen, dan limpasan di das rejoso kabupaten pasuruan menggunakan arcswat - Analysis of the effects of land use changes on erosion, sediment, and runoff in Rejoso Watershed, Pasuruan Regency using Arcswat. Teknik Pengairan Universitas Brawijaya.

Kent, C.R., Pandey, S., Tumer, N., Dickinson, C.G., and Jamieson, M. 2019. Estimating current and historical groundwater abstraction from the Great Artesian Basin and other regional- scale aquifers in Queensland, Australia. Hydrogeology Journal, 28(1), 391-412. Doi, 10.1007/s10040-019-02074-0

Khairani, D., Harisuseno, D., \& Suhartanto, E. (2018). Penerapan Metode Standardized Precipitation Index ( Spi ) Dan Effective Drought Index ( Edi ) Untuk Mengestimasi Kekeringan Di Das Rejoso Kabupaten Pasuruan - Application of the Standardized Precipitation Index (SPI) and Effective Drought Index (EdI) Methods to Estimating Drought in Rejoso Watershed, Pasuruan Regency. Jurnal Mahasiswa Jurusan Teknik Pengairan, 3(2), 112.

Khasanah, N., Tanika, L., Pratama, L.D.Y., Leimona, B., Prasetyo, E., Marulani, F., Hendriatna, A., Zulkarnain, M.T., Toulier, A., and van Noordwijk, M. (2021). Groundwater-Extracting Rice Production in the Rejoso Watershed (Indonesia) Reducing Urban Water Availability: Characterisation and Intervention Priorities. Land, 10(586), 1-28. https://doi.org/10.3390/ land 10060586

Luo, N., \& Illman, W. A. (2016). Évaluation Automatique Des Paramètres Des Aquifères À Partir D’Enregistrements De Longues Durées De Pompages Pour La Distribution D'Eau Et D’Injections. Hydrogeology Journal, 24(6), 1443-1461. https:// doi.org/10.1007/s10040-016-1407-x

Massuel, S., Amichi, F., Ameur, F., Calvez, R., Jenhaoui, Z., Bouarfa, S., Kuper, M., Habaieb, H., Hartani, T., \& Hammani, A. (2017). Prendre en compte l'utilisation des eaux souterraines pour améliorer l'évaluation des pompages d'eaux souterraines pour l'irrigation dans le Nord de l'Afrique. Hydrogeology Journal, 25 (6), 1565-1577. https://doi.org/10.1007/s10040-017-1573-5

Medellín-Azuara, J., MacEwan, D., Howitt, R. E., Koruakos, G., Dogrul, E. C., Brush, C. F., Kadir, T. N., Harter, T., Melton, F., \& Lund, J. R. (2015). Analyse hydro-économique des pompages d'eaux souterraines pour l'agriculture irriguée dans la vallée Centrale en Californie, Etats Unis d'Amérique. Hydrogeology Journal, 23(6), 1205-1216. https://doi.org/10.1007/s10040-0151283-9

Nahar, L. (2016). Studi Deskriptif tentang Strategi Badan Penanggulangan Bencana Daerah Kabupaten Pasuruan dalam Penanggulangan Bencana Kekeringan di Wilayah Kabupaten Pasuruan - A Descriptive Study on the Strategy of the Pasuruan Regency Regional Disaster Management Agency in Managing Drought Disasters in Pasuruan Regency Area. Jurnal Kebijakan Dan Manajemen Publik, 4(2), 18-26. http://journal.unair.ac.id/ download-fullpapers-kmp195f96ff77full.pdf

Ohmer M., Liesch T., Geoppert N., G. N. (2017). On the Optimal Selection of Interpolation Methods for Groundwater Contouring: An Example of Propagation of Uncertainty Regarding Inter-Aquifer Exchange. Advance in Water Resources, 109, 121-132.

Puspowardojo, S. (1984). Hydrogeology Map, Sheet X: Kediri (Java). Direktorat Geologi Tata Lingkungan.

Salameh, E and Tarawneh, A. (2017). Assessing the impacts of uncontrolled artesian flows on the management of groundwater resources in the Jordan Valley. Environmental Earth Sciences, 76(7), 1-14. Doi, 10.1007/ s12665-017-6610-0

Santosa, S., and Suwarti, T. (1992). Geology Map of The Malang Quadrangle, Java. Geology Research and Development.

Schlager, E. (2006). Challenges of governing groundwater in U.S. western states. Hydrogeology Journal, 14(3), 350360. https://doi.org/10.1007/s10040-005-0012-1

Shrestha, G., Uchida, Y., Kuronuma, S., Yamaya, M., Katsuragi, M., Kaneko, S., Shibasaki, N., \& Yoshioka, M. (2017). Evaluation de la performance d'un système de pompe à chaleur utilisant un puits à écoulement et estimation des zones appropriées pour son installation dans le bassin d'Aizu, Japon. Hydrogeology Journal, 25 
(5), 1437-1450. https://doi.org/10.1007/s10040-017-1536$\mathrm{X}$

Stevanovic, Z., \& Iurkiewicz, A. (2009). Groundwater management in northern Iraq. Hydrogeology Journal, 17 (2), 367-378. https://doi.org/10.1007/s10040-008-0331-0

Subekti, S. (2012). Studi Identifikasi Kebutuhan Dan Potensi Air Baku Air Minum Kabupaten Pasuruan - Study on Identification of Bulk Water Needs and Potentials for Drinking Water in Pasuruan Regency. Jurnal Momentum UNWAHAS, 8(2), 114808.

Taher, T., Bruns, B., Bamaga, O., Al-Weshali, A., \& van Steenbergen, F. (2012). Gouvernance locale de nappe au Yémen: Construire sur les traditions et permettre aux communautés d'établir de nouvelles règles. Hydrogeology Journal, 20(6), 1177-1188. https://doi.org/10.1007/s10040 -012-0863-1

Taher, T. M. (2016). Gestion de l'exploitation des eaux souterraines dans le Bassin de Sana'a, Yemen: approche d'une collectivité locale. Hydrogeology Journal, 24(6), 1593-1605. https://doi.org/10.1007/s10040-016-1435-6

Telford, W.M., Geldart, L.P., and Sheriff, R.E. 1990. Apllied Geophysic $2^{\text {nd }}$ Ed. Cambridge: Cambridge University Press.

Todd, D.K and Mays, L. . (2005). Groundwater Hydrology. John WIley and Sons, Ltd.

Toulier, A., Baud, B., Montety, V. De, Lachassagne, P., Leonardi, V., Pistre, S., Dautria, J., \& Hendrayana, H. (2019). Journal of Hydrology: Regional Studies Multidisciplinary study with quantitative analysis of isotopic data for the assessment of recharge and functioning of volcanic aquifers : Case of Bromo-Tengger volcano, Indonesia. Journal of Hydrology: Regional Studies, 26(October), 100634. https://doi.org/10.1016/ j.ejrh.2019.100634

Velasco, A., \& Capilla, J. E. (2019). Hydrogeological characterization and assessment of anthropic impacts in the Lower Piura Sub-basin Aquifer in Peru. Hydrogeology Journal, 27(8), 2755-2773. https:// doi.org/10.1007/s10040-019-02027-7

Yan, X., Dong, W., Li, R., Cui, L., \& Zhu, G. (2019). Assessment and validation of confined aquifer vulnerability based on the VEBHAT method: a case study in Heilongjiang Province, northeastern China. Hydrogeology Journal, 27(7), 2551-2561. https:// doi.org/10.1007/s10040-019-02022-y 